\title{
Ethnobotanical survey of plants with toxic active constituents, grown in the municipality of Cuité, Paraíba, Brazil
}

\author{
Levantamento etnobotânico de plantas com princípios ativos \\ tóxicos, cultivadas no município de Cuité, PB, Brasil
}

Recebido em: 03/04/2017

Aceito em: 28/08/2017

Diégina Araújo FERNANDES ${ }^{1}$; Aline dos Santos FRANÇA ${ }^{1}$; Rita de Cássia Fragoso de FREITAS ${ }^{1}$; Edileuza Bezerra de ASSIS ${ }^{1}$; Júlia Beatriz Pereira de SOUZA ${ }^{1}$; Flávia Negromonte SOUTO MAIOR ${ }^{1}$; Carlos Alberto Garcia SANTOS$^{2}$; Danielly Albuquerque da COSTA ${ }^{3}$ ${ }^{1}$ Academic Health Unit, Federal University of Campina Grande. Site Olho D'agua da Bica, CEP 58175-000. Cuité, PB, Brazil. ${ }^{2}$ Academic Unit of Education, Federal

University of Campina Grande, Site Olho D'agua da Bica, CEP 58175-000.

Cuité, PB, Brazil. ${ }^{3}$ Nucleus of Studies and Homeopathic and Phytotherapeutic

Researches, Department of Physiology and Pathology, Health Sciences Center, Federal University of Paraiba, City University, s/ $n$. Castelo Branco, CEP 58.051900.João Pessoa, PB, Brazil.E-mail:ac_danielly@hotmail.com

\section{ABSTRACT}

Incidents involving plants have been a major problem for public health over the years and represent the fourth leading cause of poisoning in Brazil, leading to death many people, especially children. This study aimed to carry out an ethnobotanical survey of plants with toxic active constituents, grown in the municipality of Cuité, Paraíba, correlating the popular and scientific knowledge. This study conducted an exploratory and descriptive field research by applying semi-structured questionnaires to city dwellers who maintained frequent contact with plants. The identification of 19 toxic species and 18 potentially poisonous species was possible. Prevalent plants in homes were ornamental. Most respondents were senior women who carried out this practice over ten years, and this interest in cultivation had come through relatives. The survey showed that most interviewees unaware the toxic potential of cited plants, which indicates the need to carry out educational and preventive work among the population.

Keywords: plants; public health, poisoning, ethnobotany

\section{RESUMO}

Incidentes envolvendo plantas têm sido um grande problema para a saúde pública ao longo dos anos e representam a quarta principal causa de intoxicação no Brasil, levando à morte muitas pessoas, especialmente crianças. Este estudo teve como objetivo realizar um levantamento etnobotânico de plantas com constituintes ativos tóxicos, cultivadas no município de Cuité, Paraíba, e correlacionar o conhecimento popular com o científico. Realizou-se uma pesquisa de campo exploratória e descritiva, aplicando questionários semi-estruturados para os moradores da cidade que mantinham contato freqüente com plantas. A identificação de 19 espécies tóxicas e 18 espécies potencialmente tóxicas foi possível. As plantas prevalentes nas residências foram as ornamentais. A maioria dos entrevistados eram mulheres idosas, realizam esta prática ao longo de dez anos e o interesse pelo cultivo surgiu através de parentes. A pesquisa mostrou que os moradores desconhecem o potencial tóxico das plantas citadas, o que indica a necessidade de realizar um trabalho educativo e preventivo junto à população.

Palavras-chave: plantas; saúde pública, envenenamento, etnobotânica 


\section{INTRODUCTION}

Toxic plants are those that cause damage to health by contact, inhalation or ingestion and may even lead to death. Some substances found in these plants may cause undesirable reactions and the quality of cultivation, or inadequate collecting and extraction of plant constituents can make them dangerous (1).

Ethnobotany is the study of the interaction of human societies past and present with plants. This kind of research, growing in Brazil and worldwide is based on the collecting of plants and information about their use. With this also increases the interest and knowledge about the chemical components of the plants being discovered medicinal and toxic species. This latter, feared by many people and poorly utilized by others may lead a great risk to the population that does not know about them $(2,3)$.

According to the Ministry of Health annually in Brazil, there are about 2,000 cases of poisoning by plants of which $5 \%$ occur in animals and the other $95 \%$ with humans (4). For every ten reports of poisoning in humans, six occur in children younger than nine years, usually for plants grown within the home or in public places such as schools. Adverse reactions among adolescents and adults are also common and is caused mainly by the inappropriate use of medicinal plants, hallucinogenic and abortive (5).

Poisoning caused by plants is becoming a serious problem for public health and the economy over the years. Accidents with toxic plants represent the fourth leading cause of poisoning in Brazil with loss of human life and have been causing untold financial damage to the government with the need to maintain emergency services in hospitals (6).

Thus, this study conducted an ethnobotanical survey of plants that have active principles with toxic effects in the municipality of Cuité, PB, Brazil to contribute to the knowledge of the population of this area reducing the indiscriminate use and poisoning that has been a serious health problem for many people over the years.

\section{METHODS}

Studied area. Cuite is a municipality in the State of Paraíba in the Northeast Region of Brazil with an area of $741.840 \mathrm{~km}^{2}$. It's located in Curimataú Westerner small area, in the Paraíba Agreste Mesoregion with geographic coordinates: $06^{\circ} 29^{\prime} 01$ "S and 36 $06^{\circ} 13^{\prime}$ "
$\mathrm{W}$ and belongs to caatinga biome with an altitude of 661 meters above sea level. According to the Brazilian Institute of Geography and Statistics (IBGE), Cuité has an estimated population of 20,299 inhabitants, with a population density of 26.9 people per $\mathrm{Km}^{2}$ (7).

Data collection and ethnobotanical method employed. The research was conducted between March and December 2014 and had an exploratory character - using bibliographic and documentary survey; a descriptive - exposing the characteristics of the population under study; and a field character - by requesting information to the community about the problem studied (8).

Interviews were conducted with the application of a semi-structured questionnaire, through visits at 25 homes, three schools (State Elementary School Orlando Venâncio dos Santos, State Elementary School André Vidal de Negreiros and County Elementary School Celina Lima Montenegro); three squares (Claudio Gervásio Furtado Square, José Bianor da Fonseca Youth Square and Square of Filgueiras); one Center for Psychosocial Care (CAPS-I); and Federal University of Campina Grande (UFCG).

Information was collected regarding the personal data of the participants, plants and cases of poisoning.

This study was approved by the Research Ethics Committee of the University Hospital Alcides Carneiro (HUAC) of Campina Grande, Paraiba being carried out according to the guidelines and regulations for research involving human beings of Resolution 196/96 of the National Health Council. CAAE: 25401813.5.0000.5182.

Inclusion criteria were subjects who cultivate plants or had frequent contact with these in their routine and who agreed to participate in the interviews by the Consent and Informed Document (IC). Individuals were excluded after refusing to cooperate; did not sign the IC, or had any cognitive limitation.

During the interview, whenever possible two samples were collected from each plant material in flowering period. The first sample was placed in a glass container with lid in ethyl alcohol $96 \%$ (VETEC) to the conservation of fresh plant and the second was used for making voucher specimen, both being deposited in the Herbarium of UFCG, campus Cuité. Some plants were large sized or were not in the flowering period; therefore, they were not collected. However, these species were well-known and so were identified by photographs obtained through a digital camera Sony Cyber-shot DSC-HX1 model. All plant specimens were identified 
by the botanist Prof. Dr. Carlos Alberto Garcia Santos. Data analysis was done by compiling the information obtained in the survey and comparison with the literature, using percentage values whenever appropriate.

\section{RESULTS AND DISCUSSION}

During the research, 34 sites were visited, chosen by city dwellers indications. However, only 31 people were interviewed. One of the individuals refused to participate; and a single person, a gardener, provided information about the species cultivated in three of the visited squares.

Profile of respondents. Among the interviewees, the female gender prevailed $(80.65 \%)$. The age of the people ranged between 39 and 85 years old, predominating age group between $60-69$ years $(29.00 \%)$, as shown in Figure 1. Data demonstrate that knowledge about plant species was quite limited to older people. This result can be attributed to lack of interest of young people for traditional practices, getting this culture lost over time.

Many respondents did not know the plants growing in their gardens and the toxic potential of them. Most citations of plant species were done by literate people (74.20\%), but no relation was observed between the level of education and knowledge about the management of cultivated plants (9).

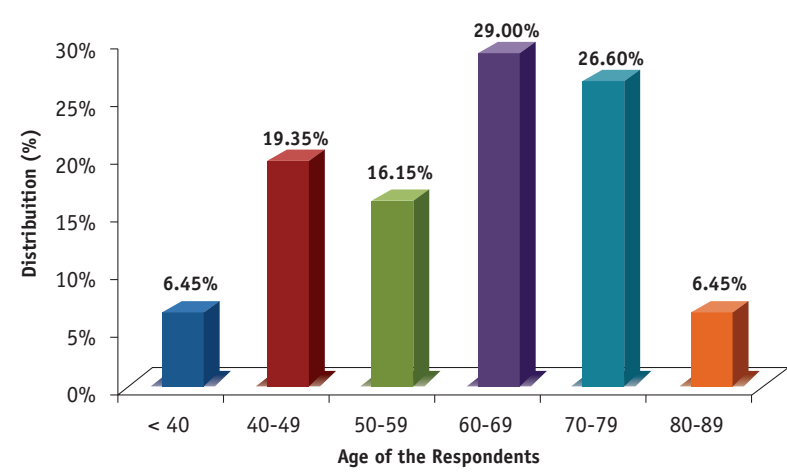

Figure 1. Age distribution of the respondents in the municipality of Cuité, PB, Brazil (2014).

Concerning the profession of the interviewees, they were predominantly retirees $(35.48 \%)$ and farmers (29.02\%), according to Figure 2. Performing visits to various locations, as schools and squares, allow the involvement of different professionals in the research, aggregating diverse knowledge about the cultivation of the plants.
Information about the collected species. According to Silva (2006), in Brazil are known 113 toxic plants, 38 registered in the Northeast Region (9). In more recent data reported for the State of Paraiba, the presence of 35 poisonous species was detected and is essential to conduct studies on poisoning since still there are many plants to be studied and identified (10).

The research resulted in a total of 96 plants, which had their identification performed by photo $(n=61)$ or botany characterization of collected specimens $(n=35)$. In literature were found proven toxicity for 19 of these plants, as shown in Table 1 and toxic potential for 18 others (Table 2).

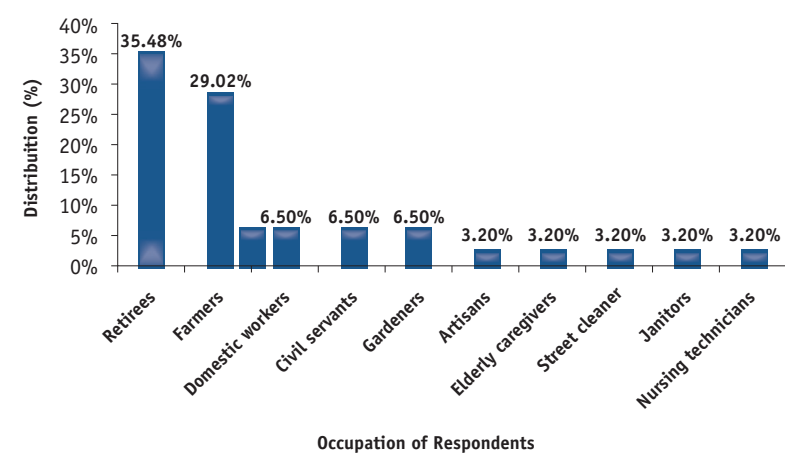

Figure 2. Occupation of the interviewed in the municipality of Cuité, PB, Brazil (2014).

There are numerous chemical components in toxic plants such as calcium oxalate, alkaloids, cardioactive glycosides, toxalbumins, cyanogenic glycosides, tannins, saponins, and all are able of causing accidents, often severe, to the health of the living being (3). In the Tables 1 and 2, can be observed that, besides the first four toxic principles previously mentioned, diterpenic esters should also be emphasized since they are the most common compounds found in the poisonous species studied.

Considering the origin of the identified plants, the majority $(59.46 \%)$ is native, being part of the Brazilian biodiversity and other $40.54 \%$ are exotic species.

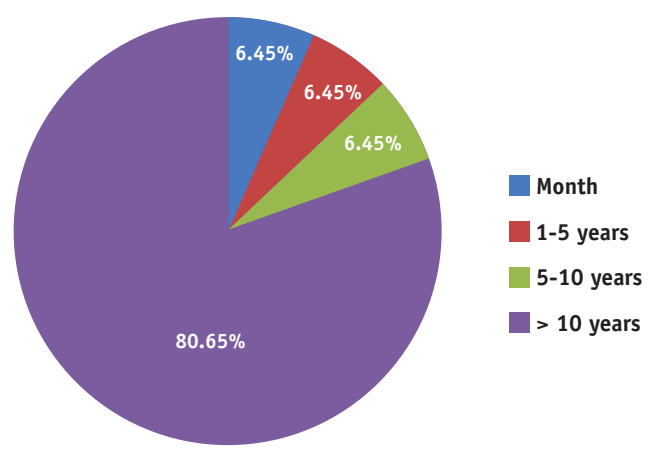

Figure 3. Distribution of the interviewees in relation to the time growing plants in the municipality of Cuité, PB, Brazil (2014). 
Apocynaceae and Araceae were the most cited among botanical families with the most toxic species; Euphorbiaceae stood out for showing the highest number of potentially toxic species.

The toxic plants with the highest number of citations by the interviewees were: Dumbcane, Philodendron, and Snake plant. These plants are entirely inappropriate for medicinal or food purposes because usually, all its parts have toxic compounds traces. Therefore, they should be used exclusively for ornamental purposes, and it is essential to be careful while performing pruning and be warned about possible accidental ingestion, especially by children and pets (1).

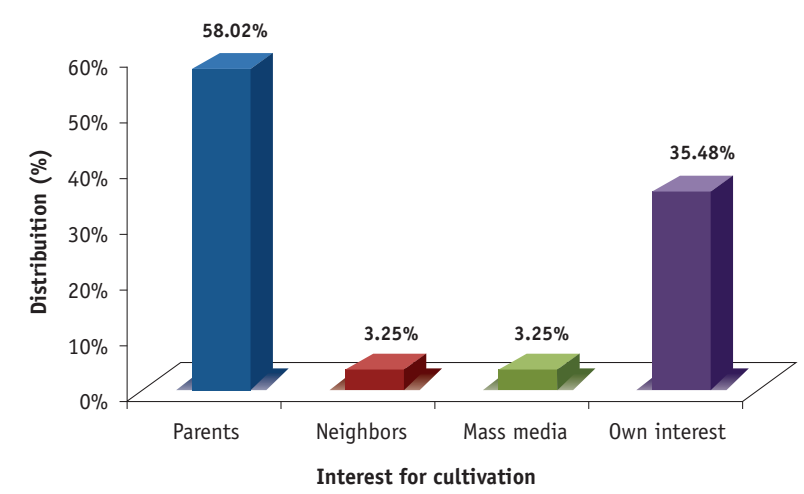

Figure 4. Reasons that motivated the interviewees to grow plants in the municipality of Cuité, PB, Brazil (2014).

Aloe vera, Madagascar periwinkle and Marvel of Peru stood out among the most cited species with toxic potential. These plants can be used for ornamental, medicinal and/or food purposes. Attention should be paid concerning the preparing and form of use because they present chemical constituents that should be avoided by some individuals.

According Rodriguez et al. (2013), the individual sensitization rate to compounds of the ingested plant, as well as the amount and form of consumption, must be taken into consideration (28).

Information about the plant species cultivated and/or used by the interviewees. The majority of respondents $(80.65 \%)$ reported that they had been growing plants about ten years and the others had been cultivating for a shorter period, as observed in Figure 3. They also indicated that the interest in plant cultivation was inherited mainly from relatives (parents, grandparents, uncles) $(58.02 \%)$ and for their benefit $(35.48 \%)$, which is a positive point since the culture of the plant cultivation is preserved (Figure 4).

Regarding the purpose of cultivation, all visited sites had ornamental species; $57.57 \%$ had plants for therapeutic purposes; and $54.54 \%$ for food use (fruits and vegetables). Considering the locations where the plants were found, $78.77 \%$ were grown at home; $18.20 \%$ in squares and schools; and 3.03\% at the University and in CAPS. It was observed, in general, that plants cultivated in the gardens of houses, had ornamental purposes. Other studies support this statistic in Acre (29), Rondônia (30), São Paulo (17), and Curitiba (31). This predominance of ornamental species in gardens may be related to the fact reported by some women who love to decorate their homes through the natural beauty of plants.

Respondents were asked how they performed the pruning of plants, and $77.45 \%$ reported having specific tools at home to carry out this activity, like garden shears, machetes, etc. However, they admitted that most of the times did not use gloves, making limited their protection. Others informants mentioned pruning their plants pulling the dried plant parts, which becomes even more worrying, due to the total lack of protection of these individuals.

According to Oliveira et al. (2002), the incidence of cases of plant poisoning in adults is associated with gardening activities, caused by latex contact with skin or by the contact of the dirty hand with eyes during pruning (32). The acute skin exposure to latex causes an inflammatory condition on the epidermis, which is characterized by redness, swelling, pain and tissue necrosis. Contact with the eyes can lead to the development of conjunctivitis, keratitis, and uveitis, along with swelling of the eyelids and eye closure due to edema (33). This type of intoxication continues to be a severe problem in the current days, as it was reported in a paper by Navarro et al. (2014) (34) and Barreto et al. (2016) (35).

\section{Knowledge of respondents on cases of poisoning} plants. About the knowledge of the informants, plants $29,00 \%$ affirmed not know which species were poisonous, and the other $71.00 \%$ said they obtained information about toxic plants through the media and from friends and relatives, but would not able to recognize or identify them in the field.

Four different kinds of toxicological exposure to plants can be defined: a) acute poisoning, that occurs after contact with skin, eyes or if swallowed; b) chronic intoxication, due continued contact, usually by accidental or intentional ingestion of certain plants; c) chronic exposure, from industrial or agricultural activities; d) abusive use of some plant species, usually due hallucinogenic or narcotic effects (36). In this study, 
acute poisoning cases were the most reported. When asked, all respondents said plants had never poisoned them. However, $16.13 \%$ reported that close relatives (spouse, children, grandchildren) had already passed through to such experience.

The following cases were reported: a) a 50-yearold man was accidentally intoxicated with dumbcane (Dieffenbachia seguine Shott.) plant, while carrying out cut parts; b) three children under five years old were intoxicated after ingestion and accidental contact with leaves of dumbcane; c) a child about 10 years old showed signs of intoxication after unintentional inhalation of smoke of jimson weed (Datura stramonium L.) flowers. The remaining respondents reported not know cases of poisoning by plant species. However they said to know that there are dangerous plants.

Concerning plants used as food, it was asked whether respondents knew that any of these could present toxic characteristics if not adequately prepared. Only $12.90 \%$ reported knowing, and two plants were cited: a) cassava (three quotes). They said that there are two species of cassava, and one of them can be toxic when not well prepared; b) kale (one quote), if is not properly cooked can cause stomach irritation. The others $(87.10 \%)$ said they did not know about this kind of poisoning.

According to a survey of the University of São Paulo, cassava can cause fatal poisoning if improperly prepared, due to the presence of some substances, mainly linamarin. Certain varieties called "wild cassava" (Manihot esculenta) accumulate higher amounts of this constituent, but without chemical analysis is not possible to distinguish them from the "meek cassava" (Manihot utilissima) (37). The linamarin occurs in more significant quantities in the root barks, but the edible white pulp contains considerable amounts of this cyanogenic glycoside. The intoxicated person can undergo a process of cellular asphyxia, and depending on the amount of cyanide in the blood can lead to death (37).

Regarding kale, reports of stomach cramps were not found. However, the literature suggests that poisoning cases involving this plant, are usually associated to misidentification of the plant, which can be confused with tree tobacco (Nicotiana glauca Graham) (11). In 2002 in the city of Ribeirão Preto, an entire family was intoxicated by tree tobacco presenting a significant content of alkaloids. Despite the literature report a few occurrences of human poisoning by their use, tobacco tree is usually among the most severe cases. Often the clinical status of patient progresses to coma followed by death (32).

Finally, respondents were asked about the providence that they would take in case of poisoning with plants. The majority $(80.65 \%)$ reported that immediately would seek medical help. The others (19,35\%) answered that they would treat poisoning at home, and having no improvement, then would find a hospital.

There are toxic substances that take effect cumulatively, but most acts on the first contact. In any case, it is safer to seek medical advice immediately. Plants considered toxic can cause various reactions from allergies of skin and mucous to cardiovascular, respiratory, metabolic, gastrointestinal and neurological disorders and, in some cases, death. So, the early treatment is crucial (38).

During data survey, respondents reported the main indications of plants described as potentially toxic. It was mentioned the use of infusion from the powder of Madagascar periwinkle flowers (Catharanthus roseus L.) for influenza. In folk medicine, all parts of this plant are considered toxic, except the roots, which are used empirically as sudorific, diuretic, hypoglycemic and febrifuge. However, no scientific studies on these indications were found (26).

Another indication mentioned was the use of oil from seeds of Barbados nut (Jatropha curcas L.) to constipation. Based on folk medicine, this plant has laxative and hemostatic effects. In literature, cases of poisoning of children and adults by excessive ingestion of seeds were found. The toxic properties of this plant are assigned to the globulin curcin, and to an acid component with similar toxicity to ricinine (39).

Guinea henweed (Petiveria alliacea) was indicated in the form of homemade syrup for treatment of influenza. In literature, the use of this plant is cautiously suggested, due to its toxic and abortive potential. Infusion is usually recommended for mouthwash in oral and throat infections, and cataplasm to treat low back pain, bruises, and trauma (26).

In Brazil, both Barbados nut (Jatropha curcas L.) as Guinea henweed (Petiveria alliacea) were included in the list of species that cannot be used for the preparation of traditional herbal products, given its high toxicity (40).

One respondent reported the use of red spiderling (Boerhavia diffusa $\mathrm{L}$.) to reduce blood viscosity, but this indication was not found in the literature. In Brazil, the roots of this plant have been widely used in folk medicine for the treatment of liver ailments such as hepatitis and 
jaundice. Cataplasm of milled and boiled red spiderling roots is used against snakebite and jigger flea (Tunga penetrans). The use for liver disorders was confirmed by researchers who showed that root extract caused liver protection in animals against introduced toxins (26).

It was reported by respondents the use of mountain ebony (Bauhinia variegata L.) flowers infusion for treatment of diabetes. According to the literature, in Brazil, many species of Bauhinia receive the popular name of pata-de-vaca, due to its leaves' shape (19). Bauhinia variegata, B. monandra and B. blackeana were introduced in Brazil with ornamental purpose and can be found in gardens and squares. Since then, they have been wrongly used by people with diabetes, instead of the recommended Brazilian species (B. fortificata and $B$. cheilantha). Because of this confusion, the use of these species should be avoided, at least until the experimental proof of the safety and efficacy (26).

The community widely knows the effectiveness of medicinal plants in the treatment of diseases. However, many users find that natural products do not need rigor in its preparation, especially about the amount of plant used and its dose. Thus, the Ministry of Health in Brazil has warned that many people are poisoned by incorrect use of medicinal plants (41). When using a home remedy made from plant parts, the body can absorb many chemicals, which can both promote beneficial actions as toxic reactions (42).

\section{CONCLUSION}

A survey about cultivated plants with toxic active principles was carried out, in the municipality of Cuité, $\mathrm{PB}$, Brazil, thus contributing to the preservation of local culture. Data show that most respondents are not aware of the toxic potential of the plants, indiscriminately using them and ignoring their toxicity. Given this fact, it becomes evident the need to complement the available knowledge about the safety and effectiveness of plant species with scientific information. This action can be accomplished by university academic projects carried out in the community, preparing information leaflets and performing informative lectures and educational campaigns on the subject. Considering the plants care and health, a better understanding of these plant species is essential to reduce the damaging effects caused by them, since these have constituted, over the years, a serious problem of public health.

\section{ACKNOWLEDGEMENTS}

The authors would like to thank the community of Cuité, PB for sharing their knowledge and allow carrying out this work. 


\section{Intarma}

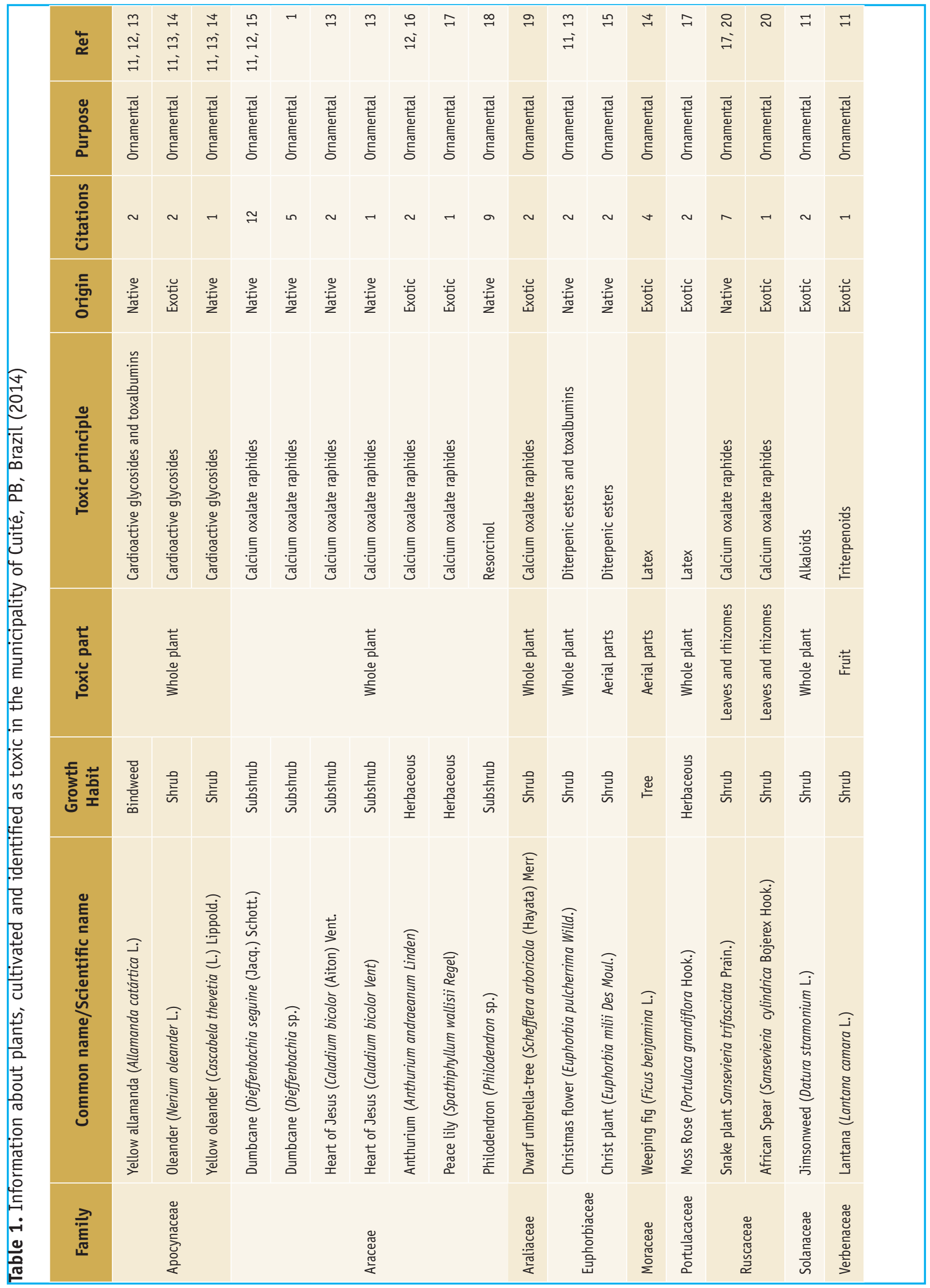




\section{Inoarma}

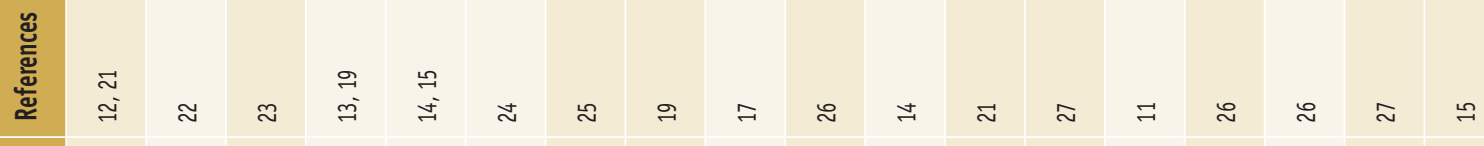

$1 / 1 \mid$

1

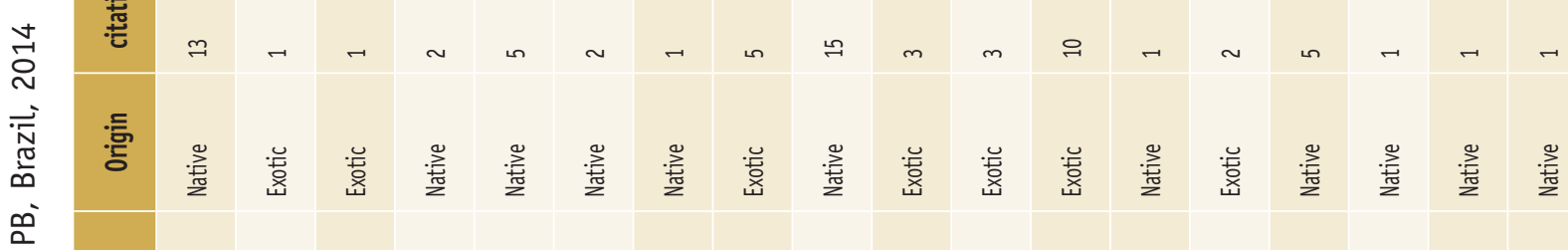

芒

.

.

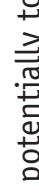

要

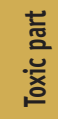

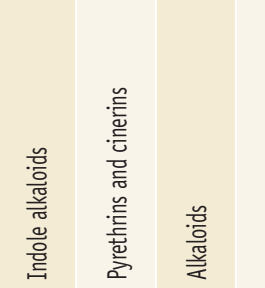

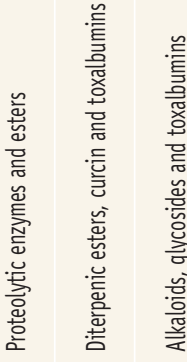

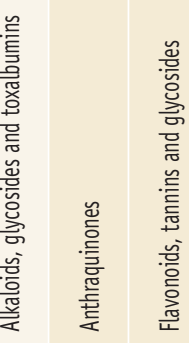

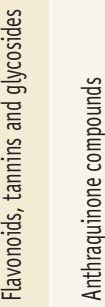

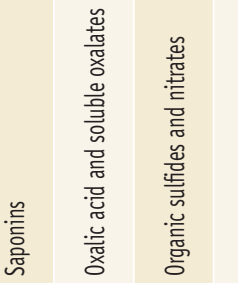

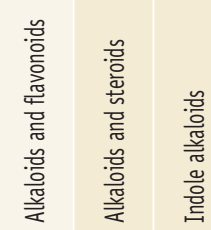

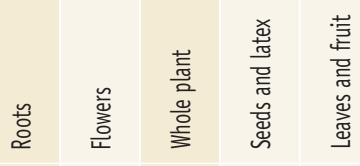

$\frac{\sqrt[n]{\frac{0}{\pi}}}{\frac{\pi}{4}}$

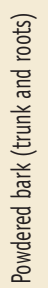

产

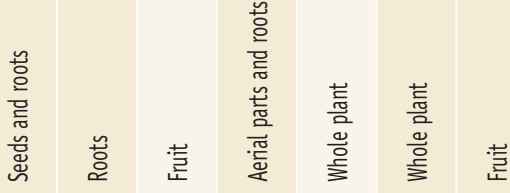

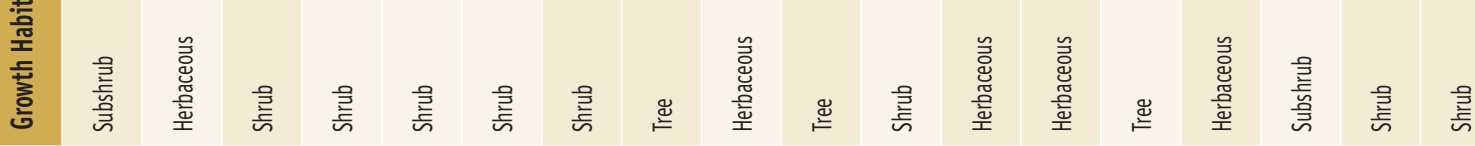

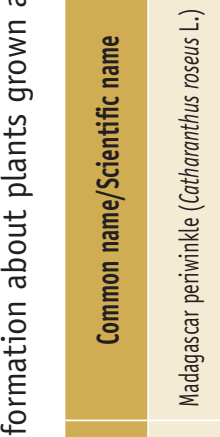

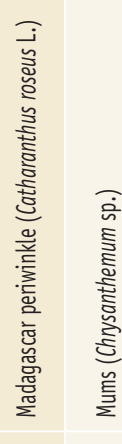
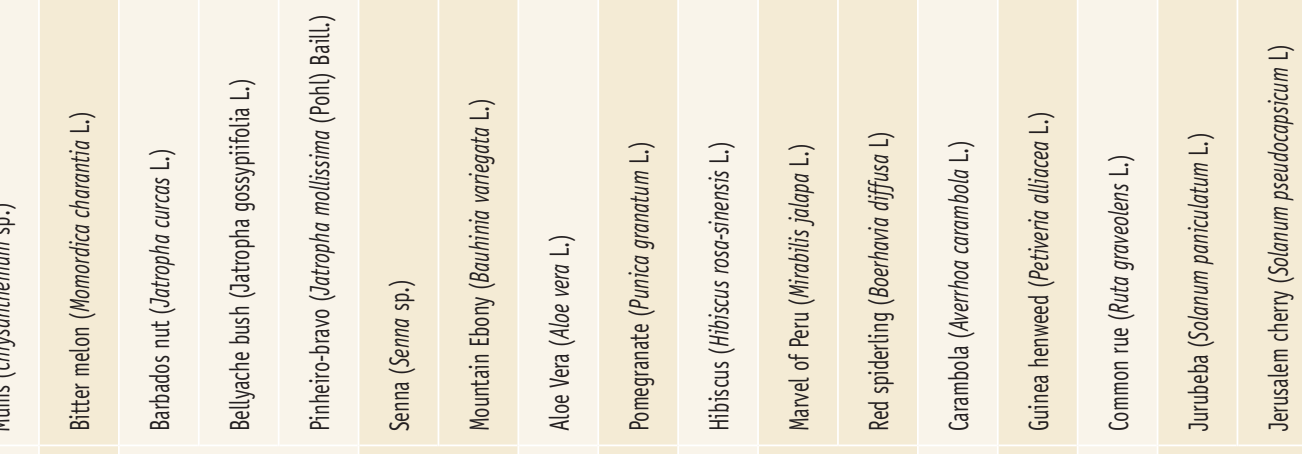

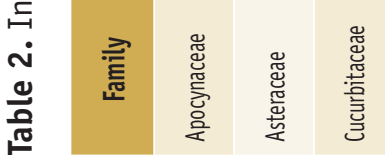

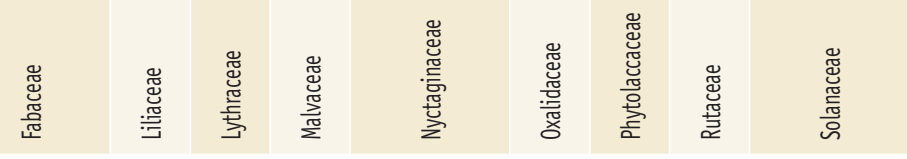




\section{REFERÊNCIAS}

1. Mendieta MC, Souza ADZ, Ceolin S, Vargas NRC, Ceolin T, Heck, RM. Plantas tóxicas: importância do conhecimento para realização da educação em saúde. Rev Enferm Online. 2014; 8 (1): 680-686. DOI: 10.5205/reuol.5149-42141-1-SM.0803201424.

2. Ricardo, LGP. Estudos etnobotânicos e prospecção fitoquímica de plantas medicinais utilizadas na comunidade do Horto, Juazeiro do Norte-CE. [Dissertação]. Patos (PB): Universidade Federal de Campina Grande; 2011. Disponível em: http://www.cstr.ufcg.edu.br/ppgcf/ dissertacoes/documentos_2011/luisiane_gondim_pereira_de_souza_ricardo/luisiane_gondim_pereira_de_souza_ricardo.pdf.

3. Teixeira IF. Plantas ornamentais tóxicas: beleza e riscos. Sistema de Informação de Projetos de Pesquisa, Ensino e Extensão da Universidade Federal do Pampa. 2011. Disponível em: file://C:/Users/Cliente/Downloads/Plantas_ornamentais_t $\% \mathrm{C} 3 \% \mathrm{~B} 3 \mathrm{xicas}$ Beleza_e_riscos $\% 20$ (1).pdf.

4. Fabiano PO, Francisco O, organizadores. Plantas tóxicas: intoxicações causadas por espécies ornamentais devido à falta de informações, em Ourinhos-SP. In: VIII Congresso de Iniciação Científica; 2009. p. 9-13.

5. SINITOX.Sistema Nacional de Informações Tóxico Farmacológicas. Registro de intoxicações. Dados nacionais. Centros de informação. Brasil; 2013.

6. Silva GAR, Oliveira CJ, Mass AW, Gobatto JMA. Plantas tóxicas cultivadas como ornamentais nos jardins da cidade de Uruçuí, Piauí, Brasil. In: Encontro de Inovação Tecnológica e Ensino de Ciências do campus Picos; 2013. p. 91-92.

7. IBGE. Instituto Brasileiro de Geografia e Estatística. Censo demográfico. Brasil; 2010.

8. Gil AC. Métodos e técnicas de pesquisa social. 6. ed. São Paulo: Atlas S.A.; 2008.

9. Silva DM. Plantas tóxicas para ruminantes e equídeos no Seridó ocidental e Seridó oriental do Rio Grande do Norte-RN. Pesq. Vet. Bras. 2006; 26 (4) 223-236.

10. Assis TS. Intoxicações por plantas na Paraíba-PB. [Dissertação]. Patos (PB): Universidade Federal de Campina Grande; 2009. Disponível em: http://www.cstr.ufcg.edu. br/ppgmv/dissertacoes/dissertacoes/2009/tales_santos assis.pdf.

11. Matos FJA, Lorenzi H, Santos LFL, Matos MEO, Silva MGV, Sousa MP. Plantas Tóxicas: estudo de Fitotoxicologia Química de Plantas Brasileiras. 1 ed. São Paulo: Instituto Plantarum de Estudos da Flora; 2011.

12. Rodrigues CFC, Nunes TRS, Araújo BC, Viana DCF. Propriedades terapêuticas da planta confrei (Symphytum offcinale): uma revisão sistemática. In: Terceiro Encontro Brasileiro para Inovação Terapêutica: Interligando competências científicas, tecnológicas e industriais em espaços de saúde 2013; Jaboatão dos Guararapes.
13. Barg DG. Plantas tóxicas. São Paulo: FACIS, 2004. Disponível em: http://www.ppmac.org/sites/default/files/ plantas_toxicas.pdf.

14. Silva $\mathrm{OH}$. Avaliação da arborização de acompanhamento viário da cidade de São Tomé, Paraná. [Monografia] Campo Mourão (PR): UTFPR; 2013. Disponível em: http:// repositorio.roca.utfpr.edu.br/jspui/bitstream/1/1621/1/ CM_COEAM_2013_1_21.pdf.

15. Lira EG, Ker DBS. Recuperação da coleção viva de plantas ornamentais tóxicas da FAV-UnB [Monografia]. Distrito Federal (DF): Universidade de Brasília; 2013. Disponível em: http://bdm.unb.br/bitstream/10483/4732/6/2013_EllenGrippiLira_DiogoBretasSousaKer.pdf.

16. Medeiros LFS, Pereira M. Espécies com princípios tóxicos, empregados na arborização urbana do bairro Nossa Senhora das Graças-Miguelópolis, SP. Nucleus 2008;5 (2): 209-220. DOI: 10.3738/1982.2278.103.

17. Trotta J, Messias PA, Pires AHC, Hayashida CT, Camargo C, Futemma C. Análise do conhecimento e uso popular de plantas de quintais urbanos no estado de São Paulo, Brasil. Rev Est Ambientais 2012; 14 (3): 17-34.

18. Santos APB. Beleza, a popularidade, a toxicidade e a importância econômica de espécies de Araceas. Rev Virt Quim 2011; 3 (3): 181-195.

19. Haraguchi LMM, Carvalho OB. Plantas medicinais. São Paulo: Secretaria Municipal do Verde e do Meio Ambiente. Divisão Técnica Escola Municipal de Jardinagem; 2010. Disponível em: http://www.prefeitura.sp.gov.br/ cidade/secretarias/upload/meio_ambiente/arquivos/plantas_med_web.pdf

20. Silva LC. Plantas ornamentais tóxicas presentes no Shopping Riverside Walk em Teresina-PI. REVSBAU, 2009; 4 (3): 69-85.

21. Cavalcanti MLF, Dantas IC, Lira RS, Oliveira JMC, Albuquerque HNA, Albuquerque ICS. Identificação dos vegetais tóxicos da cidade de Campina Grande, PB. Rev Bio Ciênc Terra 2003; 3 (1): 1-13.

22. Carvalho LM. Artemísia. Aracaju, SE: Embrapa Tabuleiros Costeiros; 2009. Disponível em: https://www. embrapa.br/tabuleiros-costeiros/busca-de-publicacoes/-/ publicacao/372812/artemisia.

23. Rigotti MS. A cura pelas plantas. In: Melão-de-são-caetano (Momordica charantia L.), uma planta com potencial para a economia agrária e saúde alternativa. Faculdades Dourados 2010; Campo Grande. p. 58. Disponível em: http://www.ppmac.org/sites/default/files/melaosaocaetano_rigotti.pdf.

24. Cunha JO, Rocha JC, Almeida PM, Martins FA. Avaliação do potencial toxicológico do látex de pinhão bravo ( $a$ tropha molíssima (Pohl) Baill.). In: 65 ${ }^{\mathrm{a}}$ Reunião Anual da Sociedade Brasileira para o Progresso da Ciência. Ciência para o Novo Brasil 2013. Disponível em: http://www. sbpcnet.org.br/livro/65ra/resumos/resumos/7358.htm. 
25. Lombardo M., Kiyota S., Kaneko TM. Aspectos étnicos, biológicos e químicos de Senna occidentalis (Fabaceae). Rev Ciênc Farm Básica Apl 2009; 30 (1): 9-17.

26. Lorenzi H, Matos FLA. Plantas Medicinais no Brasil: Nativas e Exóticas. Nova Odessa, São Paulo: Instituto Plantarum, 2002.

27. Santos AM, Dantas IC. Possíveis efeitos tóxicos das plantas que constituem a bebida "pau-do-índio". Biofar 2008; 2 (2): 63-81.

28. Rodriguez LT, Mello LA, Gasparetto M, Morandi Filho WJ. Plantas ornamentais tóxicas ocorrentes no Instituto Federal Catarinense-campus Camboriú. In: Mostra Nacional de Iniciação Científica e Tecnológica Interdisciplinar. Instituto Federal Catarinense, 2013; p. 1-5. Disponível em: http://micti-2013.ifc.edu.br/anais/resumos/ trab00133.pdf.

29. Siviero A, Delunardo TA, Haverroth M, Oliveira LC, Mendonça AMS. Cultivo de espécies alimentares em quintais urbanos de Rio Branco, Acre, Brasil. Acta Bot. Bras.2011; 25 (3): 549-556. DOI: 10.1590/S010233062011000300006.

30. Brizidio AK, Nunes RO. Composição florística dos quintais nos bairros Floresta e Texeirão na cidade de Cacoal, Rondônia. Rev Cient Facimed 2010; 2 (2): 195-210.

31. Gomes GS. Quintais agroflorestais no município de Irati-Paraná, Brasil: agrobiodiversidade e sustentabilidade socioeconômica e ambiental. [Dissertação]. Curitiba (PR): Universidade Federal do Paraná; 2010. Disponível em: www.floresta.ufpr.br/defesas/pdf_br/2010/t295 0330-D.pdf.

32. Oliveira RB, Godoy AS, Costa F. Plantas Tóxicas em Ribeirão Preto: conhecer para prevenir acidentes. 1 ed. São Paulo: Holos, 2002.
33. Ferreira AF, Fonseca KC, Canabrava HAN, Oliveira F. Purificação e caracterização bioquímica parcial de proteases existentes no látex da planta Euphorbia millii (Des) Moulins. Rev Horiz Cient 2009; 3 (2): 1-23.

34. Navarro ES, Rodríguez MDC, Patterson DC, Arcia IR. Intoxicación por tóxico vegetal de la planta Ackee. Report de um caso. Mediciego 2014; 20 (2): 1-3.

35. Barreto AS, Guzmán J, Gutiérrez JC. Intoxicación por uso recreativo de 'floripondio', reporte de caso. Rev. Med. Risaralda 2016; 22 (1): 68-70.

36. Costa TO, Almeida OS. O conhecimento popular e o risco de intoxicação por ervas medicinais. EFDeportes 2014. Disponível em: http://www.efdeportes.com/efd194/o-risco-de-intoxicacao-por-ervas-medicinais.htm.

37. IB-USP Instituto de biociências da Universidade de São Paulo. Plantas tóxicas. São Paulo, 2014. p. 77-88.

38. Vasconcelos J, Vieira JGP, Vieira EPP. Plantas tóxicas: conhecer para prevenir. Rev Cient UFPA 2009; 7 (1): 1-6.

39. Arruda FP, Beltrão NEM, Andrade AP, Pereira WE, Severino LS. Cultivo de pinhão manso (Jatropha curcas L.) como alternativa para o semiárido nordestino. Rev Bras Ol Fibros 2004; (1): 789-799.

40. BRASIL. Resolução RDC no 26 de 13 de maio de 2014. Dispõe sobre o registro de medicamentos fitoterápicos e o registro e a notificação de produtos tradicionais fitoterápicos. Agência Nacional de Vigilância Sanitária 2014; 13 mai.

41. Fernandes JM. Plantas medicinais com potencial tóxico: "mato que mata". Educação Ambiental em Ação 2008; (23).

42. Silva RP, Almeida AKP, Rocha FAG. Os riscos em potencial do uso indiscriminado de plantas medicinais. In: V Congresso de Pesquisa e Inovação da Rede Norte Nordeste de Educação Tecnológica. Instituto Federal de Alagoas, 2010; p. 1-7. 